\title{
RECLAIM THE STREETS, THE PROTESTIVAL AND THE CREATIVE TRANSFORMATION OF THE CITY
}

ANDRÉ CARMO ${ }^{1}$

\begin{abstract}
The main goal of this article is to reflect upon the relationship between creativity and urban transformation. It stems from the assumption that creativity has a paradoxical nature as it is simultaneously used for the production of the neoliberal city and by those seeking to challenge it and build alternative urban realities. First, we put forth a critical review of the creative city narrative, focused on Richard Florida's work, as it progressively became fundamental for the neoliberal city. Afterwards, and contrasting with that dominant narrative, we describe a trajectory of Reclaim the Streets that provides the basis for our discussion of the protestival (protest + carnival) as its main creative force of urban transformation.
\end{abstract}

Keywords: Creativity, urban transformation, Reclaim the Streets, protestival.

Resumo - RECLAIM THE STREETS, O PROTESTIVAL E A TRANSFORMAÇ̃̃O CRIATIVA DA CIDADE. O principal objetivo deste artigo é refletir sobre a relação existente entre criatividade e transformação urbana. Parte-se do princípio de que a criatividade tem uma natureza paradoxal, na medida em que é simultaneamente usada para a produção da cidade neoliberal, mas também por aqueles que procuram desafiá-la e construir realidades urbanas alternativas. Primeiro, fazemos uma revisão crítica da narrativa da cidade criativa, focada no trabalho de Richard Florida, por esta se ter progressivamente tornado fundamental para a cidade neoliberal. Depois, e contrastando com essa narrativa dominante, descrevemos uma trajetória do Reclaim the Streets que providencia a base para a nossa discussão do protestival (protesto + carnaval) como a sua principal força criativa de transformação urbana.

Palavras-chave: Criatividade, transformação urbana, Reclaim the Streets, protestival.

Résume - RECLAIM THE STREETS, LE PROTESTIVAL ET LA TRANSFORMATION CRÉATRICE DE LA VILLE . L'objectif principal de cet article est d'interroger le rapport entre la créativité et la transformation urbaine. Il s'appuie sur le caractère paradoxal de la créativité, dans la mesure où celle-ci est utilisée à la fois dans la production de la ville néo-libérale mais aussi par ceux qui tentent de défier celle-ci et construire des réalités urbaines alternatives. Dans un premier temps, nous effectuerons une révision critique du discours sur la ville créative en

Recebido: Dezembro 2011. Aceite: Setembro 2012.

1 Researcher, CEG-UL. E-mail: carmo@campus.ul.pt. 
nous concentrant sur l'œuvre de Richard Florida, qui s'est progressivement imposée comme fondamentale pour la ville néo-libérale. Dans un second temps et dans une perspective contrastant fortement avec la narrative dominante, nous décrirons le parcours du Reclaim the Streets, qui constitue la base de notre réflexion autour de la notion de protestival (protestation + carnaval) comme principale force créative de transformation urbaine.

Mots-clés: Créativité, transformation urbaine, Reclaim the Streets, protestival.

\section{INTRODUCTION - THE JANUS FACE OF CREATIVITY IN URBAN TRANSFORMATION}

The main goal of this article is to reflect upon the relationship between creativity and urban transformation. Cities are seen as arenas of struggle and conflict where various social forces operating in complex and often unpredictable ways take over (and remake) space(s). After all, as Gregson and Rose (2000) pointed out, space is a performance of power. Hence, urban transformation - and its struggles over the question of what cities are for, its uses and purposes - is at the centre of these antagonisms.

Furthermore, we consider that creativity has a rather paradoxical nature. Arguably one of the most important assets of the human mind and one of those defining traits of humanity that widens its horizon of possibilities, creativity is usually acknowledged as something that is simultaneously original and meaningful (Stein, 1953; Boden, 2004; Plucker, 2005; Sternberg, 2006; Sawyer, 2006; Richards, 2010). Moreover, it has become crucial for the production of the neoliberal city, but also for those seeking to challenge it and build alternative urban realities.

Underlying our reflection is the assumption that nowadays cities are mainly produced and organized as strategic nodes in a global network designed to maximize capital accumulation, and therefore the main role of urban space is to contribute to enhance competitiveness and economic productivity (Purcell, 2008).

In the neoliberal times we live in, urban spaces are primarily conceived in their commodity form. Due to an intensification of inter-urban competition, metropolitan areas need to differentiate themselves and the production of unique urban forms becomes crucial (Leslie, 2005). That is why, for instance, commercial branding, territorial marketing operations, and flagship-events (e.g. Olympic Games, World Cups, World Expos) in conjunction with urban redevelopment and/or regeneration projects anchored in culture (e.g. Barcelona's 22@, Dublin's Temple Bar), have acquired such relevance (Henriques, 2006; Vargas and Lisboa, 2011).

Although this is not a new phenomenon, since more than two decades ago Harvey (1989) called our attention to the rise of entrepreneurial urban strategies, it now provides such a powerful and persuasive model for urban development that it is almost as if there is no alternative to it. As Soja (2010: 65) contends, "city marketing and regional image making took over the reins of planning and policy making, leading to a vicious territorial competitiveness to attract investment and the attention 
of global tourism, now the world's largest industry". Additionally, these strategies also facilitate and promote processes of gentrification in which local authorities assume an active role in shaping the city to fit the aspirations and desires of the middle class (Smith, 2002).

The idea of the city-as-commodity and original product is therefore of upmost importance for the way contemporary capitalism operates and for its characteristic uneven geographical development. In the sense that the different social uses of cities are compressed (and often destroyed) under its economic function, it seems fair to say that the use-value of urban space is now subalternised and/or colonized by its exchange-value. As a consequence, "cities [can] never stand still, but always [have] to be on the lookout for the next big thing" (Peck, 2005: 762). As a dominant narrative, the creative city emerges at once as a product and as a producer of these processes of urban transformation.

However, as Massey (2008) points out, there are those who disagree and do not accept that the way cities are envisioned and produced is the correct way. Those resisting and criticizing the neoliberal city, challenging its dominant architecture and seeking to shed some light upon a wide range of alternative urban possibilities. As Harvey (2010: 180) argues, "urban social movements are everywhere in evidence (...). The right to participate in the making of capitalism's geography is, therefore, a contested right. While the power relations at this conjuncture unquestionably favour the combination of capital and state over everyone else, there are significant opposing forces".

Forces believing that cities should not be subordinated to the current hegemonic neoliberal ethos and its creative city narrative and that spatial justice, equality and human well-being should be fundamental goals. From this perspective cities are understood as collective creative works that should be made by/for inhabitants, thus disrupting and challenging the neoliberal imperative of economic growth, and replacing it by a deep concern with the relationship between cities and their inhabitants (Harvey, 2008; Purcell, 2008; Brenner et al., 2009). In order to produce new urban realities (Panelli, 2004), creative alternative experiences and practices clearly need to navigate carefully around the existing power structures and the dominant regimes that sustain them.

It is precisely the fundamental conflict between these contrasting ways of considering the relationships between creativity and urban transformation, which provides the background for this reflection - the city as an arena of struggle, the social production of urban space as inherently contentious (Castells, 2003). Furthermore, by revisiting the trajectory of Reclaim the Streets (RTS) as it developed within and against the neoliberal city, seeking to contest and challenge some of its most defining principles of urban production and organization, we also intend to explore how creativity progressed and at the same time gave shape to RTS's privileged force of urban transformation - the protestival.

The article starts with a critical review of the creative city - seen here as a very influential narrative providing theoretical support to the social production of 
the neoliberal city - revolving around Richard Florida's fundamental contributions. After that, a detailed description of RTS's trajectory, pointing out some of its most relevant features and singularities as an urban social movement, is put forth. Finally, we discuss the protestival as the single most relevant contribution of RTS for the creative transformation of urban space, and finish with some concluding remarks.

\section{THE CREATIVE CITY - A CRITICAL REVIEW}

According to Meusburger et al. (2009: 5) "geographers pursuing the topic of creativity focus mainly on the role and impact that milieus, contexts, or environments have on creativity, on the spatial distribution, disparities, and diffusion of creative ideas and products, on the factors constituting creative environments, and on the spillovers of knowledge from science parks and universities". Seixas and Costa (2011), in turn, argued that creativity has been studied in relation to urban development concerning the importance of cultural and creative activities in economic performances and territorial development and regarding the role frequently ascribed to the creative class in fostering competitiveness. The authors also pointed out three main areas of research. One focuses on the creative instruments and solutions devised to deal with new socio-economic and cultural contexts, the other on the role creative sectors and activities are ascribed in public policies aimed at urban development, and the third one revolves around the necessity to attract creative activities and competences linked to knowledge and innovation.

This brief overview suggests that the creative city is primarily concerned with the role of creativity as a catalyst of economic growth and competitiveness. The resonance this quasi-hegemonic narrative has had in numerous countries and institutions operating at various scales, attests the fact that it fits very well into the neoliberal understanding of the role that cities should play.

Among others, the creative city "canon" consists of scholars such as Landry and Bianchini (1995), Landry (2000), Caves (2002), Clark (2004), O'Connor (2004), Gertler and Vinodrai (2005). However, Richard Florida (2002, 2003, 2005) stands out as the most influential (and ubiquitous) voice. His seminal work The Rise of the Creative Class starts out from the assumption that the driving force behind economic and social transformations is human creativity. As Florida (2002: 4) pointed out, "both at work and in other spheres of our lives, we value creativity more highly than ever and cultivate it more intensely. The creative impulse - the attribute that distinguishes us, as humans, from other species - is now being let loose on an unprecedented scale". Although highlighting the importance of creativity in all spheres of human existence, he reduces it to a mere instrument of economic competitiveness or, in his own words, "the decisive source of competitive advantage [and] the most highly prized commodity in our economy" (Florida, 2002: 4). In the fierce and relentlessly competitive atmosphere of the 21 st century creative 
capitalism, as he puts it, creativity is definitely of utmost importance for the construction of "successful" cities. Hence, cities need to adapt to the creative class, loosely defined as those whose occupations range from artist and software designers (super-creative core) to management and legal experts (creative professionals), since they are the ones attracting high-tech and high-growth firms (Pratt, 2008). In turn, creativity and members of the creative class are attracted to places featuring what Florida calls the 3Ts of economic development: technology, talent and tolerance. Based on extensive statistical data (e.g. gay index, talent index, melting pot index, bohemian index) he suggests that "to attract creative people, generate innovation and stimulate economic development, a place must have all three" (Florida, 2003: 10). As such, the most successful cities are the ones that are able to foster a liberal and bohemian environment - socially tolerant capitalism - that is open to creativity and diversity of all sorts, thus attracting and retaining the entrepreneurial members of the creative class.

Revolving around Florida's work, the creative city has been criticized on various grounds. Chatterton (2000), for instance, argued that the creative city rhetoric is marked by a general tendency towards reductionist and simplistic understanding of urban and regional processes of development. Likewise, Scott (2006) pointed out that the $\mathrm{X} \rightarrow \mathrm{Y}$ argument (where $\mathrm{X}$ is the creative class and $\mathrm{Y}$ is local economic development), neglects the complex interrelationships underlying the emergence of a creative environment. In short, "creativity is not something that can be simply imported into the city on the backs of peripatetic computer hackers, skateboarders, gays, and assorted bohemians but must be organically developed through the complex interweaving of relations of production, work, and social life in specific urban contexts" (Scott, 2006: 15).

The creative class concept has also been accused of being built based on an oversimplified understanding of human creativity. Pratt (2008), for instance, accuses Florida of reductionism - in his work, class corresponds to a taxonomic category with unclear boundaries - and determinism - he comments causality from a mechanical classification based on income and occupation.

Research about artists and creativity in urban settings (Markusen, 2006; André and Carmo, 2010) also suggests that the creative class concept is fundamentally flawed because it is far from being homogeneous and theoretically consistent. Instead, it entails occupational categories showing different social features and spatial patterns. Arguably, the creative city fails to reflect several years of research about creativity and the complex diversity of insights coming from different areas of knowledge (Amabile, 1982, 1983; Boden, 1998; Hill et al., 1993; Sternberg and Lubart, 1999; Stokes, 2006; Richards, 2007; Huang, 2009; Kozbelt et al., 2010).

Furthermore, tool-kit approaches to the creative city seem to prioritize opportunistic rather than strategic thinking, thus marginalizing or ignoring more structural economic, political or environmental problems. In fact, more often than not, "these problems remain intact while a more sanguine story of urbanism is written through the lens of the creative city" (Chatterton, 2000: 392). Despite being able to 
harbour unprecedented creative capabilities, Scott (2006) suggested that cities are also places where striking inequalities prevail and there can be no creative city where these problems remain. This, in turn, led authors such as Peck (2005) and Raunig et al. (2011) to suggest that Florida's rationale is perfectly suited to an increasingly entrepreneurialized and neoliberalized ethos in which urban social-welfare concerns have been progressively subordinated to economic development imperatives, hence, to the endless pursuit of urban advantages. More often than not, the negative distributional consequences of this process are denied or ignored.

Similarly, Pasquinelli (2008) points out that Florida's research has been inextricably tied to economic rent and speculation, with no necessary reallocation of wealth. His research looks at society as a flat surface, totally disregarding the complex antagonisms and dynamic nature of social realities. Consequently Florida's creative economy "is based on the exploitation of the cultural capital of a given city as a driver of economic growth (...) [he] addresses a simplistic progressive political agenda with no acknowledgement of the exploitative sides of such a process" (Pasquinelli, 2008: 145).

Overall, the creative city we have been criticizing seems inconsistent and totally ignorant regarding the role of those not belonging to the so-called creative class. As Peck (2005: 758) suggested, they "seem to be little more than deadweight (...) their needs and aspirations are implicitly portrayed as wrongheaded and anachronistic, their only salvation being to get more creative".

Chatterton (2000) also pointed out that for the creative city to reach the conventional (neo) liberal audience of policy makers and politicians, it has to dilute or exclude expressions of creativity that are seemingly unsuitable. In fact, forms of graffiti and subvertising, squatting, guerrilla gardening, media forms such as indymedia, and other ways of intervening in cities that necessarily deal with ethical contradictions, conflicts, challenge, dominant social norms and laws, derive their energy from the creativity and inventiveness of participants, but are excluded from the creative city. Along similar lines Scott (2006) pointed out that the construction of a truly creative city involves basic issues of citizenship and wider concerns for conviviality and camaraderie in the urban community as a whole.

Strictly focusing on Florida's The Rise of the Creative Class, Peck (2005) also provides one of the most trenchant critiques of the creative city semantics. From the political ambivalence characteristic of Florida's writing style, "which mixes cosmopolitan elitism and pop universalism, hedonism and responsibility, cultural radicalism and economic conservatism, casual and causal inference, and social libertarianism and business realism" (Peck, 2005: 741), to his celebration of the homo creativus as "an atomized subject, apparently with a preference for intense but shallow and noncommittal relationships, mostly played out in the sphere of consumption and on the street" (Peck, 2005: 746), and the fact that he "both glorifies and naturalizes the contracted-out, "free-agent" economy, discursively validating the liberties it generates, and the lifestyles it facilitates, for the favoured class of creatives" (Peck, 2005: 756), nothing is left behind. 
Finally, because it is perhaps the most devastating critique of the creative city we would like to mention a manifesto from the world of activism, namely, from the creative class struggle group (http://creativeclassstruggle.wordpress.com/mission/):

Creative class's policies are designed to build money-making cities rather than secure livelihoods for real people. These policies celebrate a society based on inequality, in which a select group of glorified professionals is supported by an invisible army of low-wage service workers. Seduced by the promise of prosperity and growth, governments around the world are reorienting their economies along these "creative" class lines without consulting immigrants, women, coloured people, low-wage workers, and others directly affected by their decisions. Divisive "creative class" policies, implemented in the midst of the worst financial crisis since the Great Depression, serve only to increase the vulnerability of the vulnerable and further empower the powerful.

\section{REVISITING RECLAIM THE STREETS}

Reclaim the Streets (RTS) was a movement of resistance, often linked to a radical tradition, that emerged out of the collusion between multiple agents (e.g. deejays, anti-corporate activists, political and new age artists, radical ecologists) battling against the commodification of streets and public spaces.

Initially conceived as an ecologically rooted anti-road movement against the motorization of Britain, it rapidly shifted towards wider political issues such as corporate globalization, anti-capitalism and the politics of public space (Klein, 2001; Harvie et al., 2005). As opposed to most UK anti road campaigns emerging from a deep ecology/earth first background, RTS has always had its roots in both social and ecological activism.

The project of RTS was to create a link between resistance to environmental destruction, the public pleasures of carnival, the critique of social privatisation processes, the desire for alternatives to the individualised culture of auto mobility, and a general critique of neoliberal capitalism as such (Gilbert, 2008). The point was always to contrast transportation and the car against the underlying capitalist logic of enclosure, thus reclaiming all space for collective use as commons. The underlying ideas forging its collective identity were well captured in a RTS agitprop where one could read:

(...) we are basically about taking back public space from the enclosed private arena. At its simplest, it is an attack on cars as a principle agent of enclosure. It's about reclaiming the streets as a public inclusive space from the private exclusive use of the car. But we believe in this as a broader principle, taking back those things which have been enclosed within capitalist circulation and returning them to collective use as commons (Fourier, 2003: 54). 
RTS developed out of the no-M11 campaign, a local protest against the construction of a six-lane motorway cutting through 350 homes in East London and an ancient woodland, forcing the displacement of several thousand people, apparently to save six minutes on a car journey (Jordan, 2002). For over thirty years, the project had to face popular opposition, especially from local residents.

In the autumn of 1993, however, the bulldozers arrived so "it was time to develop new creative political methods, using direct action, performance art, sculpture and installation and armed with faxes, modems, computers and video cameras" (Jordan, 2002: 349). Claremont Road, a street with thirty-five terraced houses directly on the path of the M11 link road, became a landmark for the RTS. Dolly, a 92-year-old resident that became an iconic figure for this struggle and supported the RTS campaign lived there.

Acts of resistance included closing roads off to traffic while opening them to the "art of living". Instead of being used entirely as means of circulation, they became vibrant places where one could sleep, eat or walk. As Jordan (2002: 350) recalls,

(...) furniture was moved out of the houses into the road, laundry was hung up to dry, chess games were played on a giant painted chess board, snooker tables were installed, fires were lit, a stage was built and parties were held. The "road" had been turned into a "street", a street like none other, a street which provided a rare glimpse of utopia, a kind of temporary microcosm of a truly liberated, ecological culture.

Moreover, houses and streets were also transformed into barricades built to resist eviction by the Department of Transport. Hence, Claremont Road was transformed into a living sculptural fortress, involving the artistic transformation of spaces with objects such as cars or trees, used to delay or temporarily hold back the decision already made by the government. It was, in fact, the embededness of art in everyday (urban) life.

Then, in late 1994, the Criminal Justice and Public Order Act (CJPOA) was passed and civil protest criminalized contributing to unite and motivate even more the local communities and RTS. In the end, however, the no-M11 link road campaign was to be lost in what became later known as the "battle of Claremont Road" in which all the activists were evicted. When Claremont Road was levelled in November 1994, as Klein (2000: 314) pointed out "it had become the most creative, celebratory, vibrant living street in London (...) by the time all the activists had been cherrypicked out of their tree houses and fortresses, the point of the action - that high speed roads suck the life out of a city - could have had no more graphic or eloquent expression". Until that date, it remained as one of the biggest direct action campaigns ever to be made in Britain.

Eventually, in May 1995 RTS organized its first street party assembling five hundred people on Camden High Street dancing to the sound of the mobile bicyclepowered Rinky Dink sound system. It all started "when two cars careened into each 
other on Camden High Street in North London and, as their drivers set about each other's cars with hammers, a crowd of 500 people emerged from among the shoppers to redecorate the street and party the afternoon away to the tunes of a mobile sound system" (Brown, 2004: 93).

With the CJPOA in full effect, this RTS street party attracted many of those belonging to the increasingly politicized rave scene as those dancing events were also targeted by the CJPOA. According to Jordan (2002: 354), "the road became a stage for a participatory ritual theatre". Ritual, due to the fact that it produced real effects through the mobilization and enactment of symbolic causes, and participatory because street parties sought to eliminate the rigid division between performer and audience, giving everyone the right to simultaneously experience it in a "spirit of face-to-face subversive comradeship".

Two months later a second RTS street party took place in Upper Street Islington in which three thousand people gathered, with electronic music in the background creating a lively and exciting atmosphere, completed with a ton of sand poured onto the street. After all, the idea of a street party is simple enough, "decide a date and a venue, get as many people as possible to turn up, and empower everyone involved by taking away public space from cars and showing that the seeming uncertainties of everyday life can be altered to everyone's benefit and pleasure" (SchNEWS, 2000: 113-114). A meticulous and vivid description of this event was put forth by Jordan (2002: 354) as follows:

(...) imagine: it's a hot summer day, four lanes of traffic move sluggishly through the grey stinking city haze, an air horn pierces the drone of cars. Suddenly several groups of people appear running out from side street carrying 20 -foot-long scaffolding poles. In a perfectly choreographed acrobatic drill, the scaffolding poles are erected bang in the middle of the road in the form of tripods and people climb to the top, balancing gracefully 20 feet above the tarmac. The road is now blocked to traffic but open to pedestrians. Then that spine-tingling peak experience occurs. Drifting across this extraordinary scene is Louis Armstrong's voice singing "What a Wonderful World" - this wondrous sound is coming from an armoured personnel carrier which is now standing in the car-free street. Within minutes, thousands of people have filled the road.

According to Eley (2002: 478), "at the third street party on 13 July 1996, 10,000 people occupied the Shepperd's Bush Flyover on a Saturday afternoon, turning the hard shoulder into a café and stalls, the centre into a picnic site and stage, and the fast lane into a sandpit, as they danced and mingled". Once more, the temporary transformation of public spaces has been successfully achieved. At the time Britain's shortest stretch of motorway, the M41 hosted the largest festival of resistance ever. The fact that people chatted, danced, ate, met friends and made new ones in that festive landscape translates the fact that, even if only temporarily, they had won the battle: "the crowd roars - we've liberated a motorway through sheer numbers, through people power!'(Jordan, 2002: 356). Stretching across the six lanes were 
huge banners with saying like "Support the tube workers", "Destroy power", or "The society that abolishes every adventure makes its own abolition the only possible adventure".

All in all, "this street party was the perfect propaganda of the possible - it was a day full of those priceless moments where everything slips away and immense cracks appear in the façades of authority and power" (Jordan, 2002: 256).

From then onwards RTS got progressively closer to striking tube workers in London and the sacked Liverpool dockers and their families while, at the same time, strengthening their mutual relationships. This convergent path culminated in the 20,000 people March for Social Justice on 12 April 1997, three weeks before the Labour Party election victory. Under the banner "Never Mind the Ballots, Reclaim the Streets", RTS together with the dockers and striking workers from Hillingdon Hospital and Magnet kitchens stressed the need for radical social change that so many hoped the (then) imminent end of two decades of Tory rule would bring about (Brown, 2004).

For Gilbert (2008) it was in many ways RTS's finest moment as it mixed trade unionists and Trotskyites with young ravers. For the first couple of hours old and new politics were united. However, as soon as the rally ended trade unionists started to leave and the young protesters left behind felt suddenly isolated. Soon the police started a series of hostile manoeuvres intended to intimidate and provoke the remaining protesters resulting in a violent clash. Thus, unlike previous street parties this one was not successful, quite the opposite. As John Jordan (RTS organiser) noted in a recent interview (http://raforum.info/spip.php?article4613\&lang=en) "not only did it fail in that we did not manage to carry out our main plan, but also because a street party in Trafalgar Square, followed by newspaper front pages with "Anarchist Riot", "Attempted Murder", etc. is not politically effective".

Throughout the following years, RTS-inspired protests continued to take place around Britain and across the globe in places such as Tel Aviv, Helsinki, Sidney, Bogotá or New York. Klein (2000) believed that it was the combination of "rave and rage" that most contributed for the worldwide diffusion of the "RTS-model". Nevertheless, the 1997 failure was very hard to deal with and, from then onwards, RTS initiated its progressive decline.

The last major event in which RTS participated occurred on 18 June 1999 in London. In conjunction with other direct action groups (e.g. Food not Bombs, Critical Mass, London Green Peace) RTS organised what became known as J18 Carnival Against Capitalism in the London financial district. The choice of a location for the protest was not accidental, as an article published in Do or Die magazine immediately after the protest highlighted: "why not aim at the heart of the beast, the pulsating core of the global economy, the financial and banking districts, the engine room of all ecological and social devastation?"( http://www.eco-action.org/dod/no8/ j18.html ) Likewise, the event was timed to coincide with the $25^{\text {th }}$ G8 Summit in Cologne, Germany, and also with similar protests in cities around the world as the rallying slogan "Our Resistance is as Transnational as Capital" asserted. 
Thousands of people were attracted to the protest and although it may have helped to inspire the Seattle events, later that year, and to forge some international connection with anti-capitalists elsewhere, Tony Blair's New Labour government was already in the process of reinstating the postponed road-building plan, and the anti-capitalist movement in Britain almost completely disappeared from the political scene (Gilbert, 2008).

Moreover, as RTS direct actions were unable to draw in significant number of participants from the urban radical and counter-cultural milieu (Brown, 2004), the movement failed to address the gendered experience of (fear in) public spaces and to take into account the racial and ethnic dimensions of public space (McKay, 1998).

Street parties have also become "fashionable" as youth culture events. Consequently, as John Jordan noted in the aforementioned interview "one of the problems we [RTS] are constantly dealing with, and the main reason that we don't feel like doing another street party, is that we felt it was easy for the street party to be seen as JUST fun, just a party with a hint of political action".

In the end, however, RTS was to prove a lasting inspiration to protesters around the world who sought to challenge the culture of alienation, individualism and environmental destruction, thus providing a concrete glimpse of what an alternative urban reality might look like. As Gilbert (2008: 131) argued, RTS "was effective because it successfully made connections between a whole set of issues and constituencies which might otherwise have remained separated", in other words, it was "effective" because it was creative.

\section{THE PROTESTIVAL AS CREATIVE FORCE OF URBAN TRANSFORMATION}

If there is a single element that distinguishes urban social movements from other social and political actors, it is the strategic use of novel, dramatic, unorthodox and non-institutionalized acts, practices and strategies intended to shape public opinion, to put pressure on those holding authority or directly deal with the issues motivating collective action (Taylor and Dyke, 2004; Nicholls, 2007; Hamel, 2008; Alonso, 2009; ).

Additionally, as Pacione (2009) suggested, they are also characterized by their grassroots orientation, non-hierarchical mode of organization, their distance and non-involvement in formal politics, and their emphasis on direct action and protest. RTS shares several of these traits and throughout the 1990s it was able to constitute itself as one of the most relevant urban social movements.

In our view, the single most creative aspect of RTS - one that was crucial to shape its collective identity as an urban social movement - was the pivotal role it ascribed to the reinvention of political protest in public spaces as it sought to intertwine carnival, play and protest through street parties, in what came to be known 
as the protestival. It was through the protestival that RTS tried to foster the construction of alternative urban realities.

John (2004: 422) understands the protestival as a site of "creative resistance rooted in aesthetic protest and insurrectionary pleasure running from the 1960s back to the Paris Commune of 1871" that finds its inspiration in avant-garde art movements that challenge the distinction between art and protest. As opposed to conventional ritualized, uniform and predictable forms of protest and demonstration that are usually tolerated by authorities and the prevailing order (e.g. May Day celebrations, Mardi Gras, Berlin's Love Parade), the protestival creatively reclaimed a public space carnival. Hence, it became "a re-appropriation of those perennial liberations from the prevailing order, those periodic interludes of transgressive corporeality, visionary freedom and liminal community universal to the human experience" (John, 2004: 423).

In fact, protestivals created temporary participatory urban spaces where social hierarchies and established norms were effectively suspended. The protestival was an urban site where "all structures inherent or enforced in society are dissolved and all values or systems of hierarchy transposed. Not only social roles, but roles of all forms disintegrate or reverse" (Stevens, 1995: 67).

Accordingly, RTS's protestivals privileged play as multidimensional political performances. Nearly always in a non-violent manner, the movement was able to engage with the power structures of the neoliberal city while revealing and confronting their limitations and contradictions. It was also able to create a community of support and resistance, and to support a coordinated organizing effort because, as Shepard et al. (2008) pointed out, play is most useful when it is embedded in a collective effort that includes many traditional components of conventional protests.

As an expression of creativity, the protestival also shows how relevant it is to adopt a contextualized perspective. In fact, individualized approaches seem to be unable to recognize that humans are highly contextual beings and those creative forces, such as the protestival only make sense when looked at from a relational point of view. Nevertheless, perhaps more than anything else, the conjunction of play and political performance "[created] spaces where activists [felt] compelled to challenge seemingly insurmountable targets" (Shepard et al., 2008: 3). Among other issues, RTS was able to change the way people thought about the environment, the privatization of the common, the car-culture, while creatively and temporarily seeking to (re)shape material urban realities.

Firmly rooted in everyday urban experiences, protestivals celebrated dissent and the potential of human imagination in the search to build social change in the present and not in some distant future. As the protestival was based on a creative multitude, it also revealed itself as an example of small-c creativity - forms of creativity focused on the everyday life experiences and challenges of those neglected by the neoliberal city, highlighting the importance of coming up with new processes and ways of dealing with the complex circumstances of real life (; Runco, 1996; Csikszentmihalyi, 1996, 1997; Richards, 2010). Thus, as Brown (2004: 96) 
underlined, the politics of RTS "[was] not so much a goal-oriented politics, but one in which a process of conscious self-activity [was] seen as centrally important and the seed of future social revolution".

An RTS protestival crystallized a unique prefigurative spatiality creating urban experiences radically at odds with the prevailing neoliberal city. In an urban world increasingly oriented towards privately owned spaces designed to enhance economic competitiveness, RTS offered us an opportunity to reconsider and change the ways in which we relate to the collective spaces of the city.

These prefigurative spatialities, that were brought to life by RTS, seemed to share some of the constitutive elements of proposals, such as Bey's (1991) temporary autonomous zones or Curran's (2009) temporary utopian spaces, as they configured sites where activists sought to build a new urban world in the shell of the old one and to occupy spaces while subverting and liberating them from their conventional uses. Those were spaces of endless possibilities - where dissident urban inhabitants experimented with the future, enjoying the counter-spectacle of the present - allowing the reconstruction of alterity, celebrating autonomy and changing hierarchies, in which individuals collectively shaped their own contexts and created new desires.

All in all creativity was mobilized and used to produce alternative urban spaces critical of the neoliberal city and that at least temporarily escape from it. The sociospatial materialities of everyday life were temporarily reconfigured and rescued from the neoliberal city. As John (2004: 425) argued, "while the outcomes were never certain, a demonstrable "future-presence" was made possible as the carnival came to the streets, as the private road was transformed into a ludic street". However, as soon as the protestival got disseminated and accepted (and somehow subverted) by a wider community it progressively lost its resonance and political substance (Hodder, 1998).

\section{CONCLUDING REMARKS}

This article sought to question the ways creativity has been related to urban transformation. It started from the assumption that cities are spaces of struggle and contention and that creativity has a rather paradoxical nature allowing it to be used by those responsible for the production of the neoliberal city and those seeking to challenge it and build alternative urban realities.

Furthermore, a critical review of the creative city narrative - mainly revolving around Richard Florida's work - in which several theoretical and political flaws were pointed out, was also developed, in order to show how creativity has become pivotal for the ever growing commodification of urban space.

Emerging from within the neoliberal city, although clearly conflicting with it, we have revisited RTS trajectory in order to better grasp how creativity can be used to foster urban transformations in a radically different way. Next, focusing on the protestival as a creative force giving shape to temporary urban spaces of resistance 
we discussed some of its main characteristics. In the end, the protestival seems to be one of those spatial practices that requires attention and nurturing in the path towards the development of new forms of urbanity emerging from the "radical margins" (Swyngedouw and Kaika, 2003: 19).

Like the mythological figure of Sisyphus, in order to explore the various fractures and contradictions of the neoliberal city, thus promoting emancipatory and progressive urban transformation processes, alternative forces - such as RTS need to constantly reinvent themselves if they aim at surviving the tidal wave of neoliberalism.

\section{BIBLIOGRAPHY}

Alonso A (2009) As teorias dos movimentos sociais: um balanço do debate. Lua Nova, 76: 49-86.

Amabile T M (1982) Social psychology of creativity: a consensual assessment technique. Journal of Personality and Social Psychology, 43: 997-1013.

Amabile T M (1983) The social psychology of creativity. Springer-Verlag, New York.

André I, Carmo A (2010) Régions et villes socialement créatives. Étude appliquée à la Péninsule Ibérique. Innovations, 3(33): 65-84.

Bey H (1991) The temporary autonomous zone, ontological anarchy, poetic terrorism. http:// www.hermetic.com/bey/taz_cont.html [accessed 3 March 2012].

Boden M A (2004) The creative mind: myths and mechanisms. $2^{\text {nd }}$ ed. Routledge, New York and London.

Boden M A (1998) What is creativity? In Mithen S (ed.) Creativity in human evolution and prehistory. Routledge, London and New York: 15-43.

Brenner N, Marcuse P, Mayer M (2009) Cities for people, not for profit. City, 13(2-3): 176-184.

Brown G (2004) Sites of public (homo) sex and the carnivalesque spaces of reclaim the streets. In Lees L (ed.) The emancipatory city? Paradoxes and possibilities. Sage Publications, London: 91-107.

Castells M (2003) The process of urban social change. In Cuthbert A (ed.) Designing cities: critical readings in urban design. Blackwell, Oxford: 23-27.

Caves R (2002) Creative industries: contracts between art and commerce. Harvard University Press, Cambridge.
Chatterton P (2000) Will the real Creative City please stand up? City, 4(3): 390-397.

Clark T N (ed.) (2004) The city as an entertainment machine. Amsterdam, Elsevier.

Csikszentmihalyi M (1997) Finding flow: the psychology of engagement with everyday life. Basic Books, New York.

Csikszentmihalyi M (1996) Creativity: flow and the psychology of discovery and invention. Harper Perennial, New York.

Curran G (2009) (Con)Temporary utopian spaces. In Hayden P, Chamsy E (eds.) Globalization and utopia: critical essays. Palgrave Macmillan, New York: 190-206.

Eley G (2002) Forging democracy: the History of the left in Europe 1850-2000. Oxford University Press, Oxford.

Florida R (2005) The flight of the creative class: the new global competition for talent. HarperCollins, New York.

Florida R (2003) Cities and the creative class. City \& Community, 2(1): 3-19.

Florida R (2002) The rise of the creative class: and how it's transforming work, leisure, community and everyday life. Basic Books, New York.

Fourier C (2003) Reclaim the Streets: an arrow of hope. In Notes from Nowhere (eds.) We are everywhere: the irresistible rise of global anticapitalism. Verso, London.

Gertler M, Vinodrai T (2005) Anchors of creativity: how do public universities create competitive and cohesive communities? In Iacobbuci $\mathrm{F}$, Tuohy C (eds.) Taking public universities seriously. University of Toronto Press, Toronto: 293-315. 
Gilbert J (2008) Anticapitalism and culture: radical theory and popular politics. Berg, Oxford.

Gregson N, Rose G (2000) Taking Butler elsewhere: performativities, spatialities and subjectivities. Environment and Planning D: Society and Space, 18(4): 433-452.

Hamel P (2008) Ville et débat public: agir en démocratie. Les Presses de l'Université Laval, Québec.

Harvey D (2010) The enigma of capital and the crises of capitalism. Profile Books, London.

Harvey D (2008) The right to the city. New Left Review, 53: 23-40.

Harvey D (1989) The condition of postmodernity. Blackwell, Oxford.

Harvie D, Milburn K, Trott B, Watts D (eds.) (2005) Shut Them Down! The G8, Gleneagles 2005 and the Movement of Movements. Dissent!/ Autonomedia (jointly published), Leeds and Brooklin.

Henriques E B (2006) O centro histórico de Dublim (Irlanda) e a experiência de reabilitação de Temple Bar. Finisterra - Revista Portuguesa de Geografia, L(80): 47-62.

Hill K G, T M Amabile (1993) A social psychological perspective on creativity: intrinsic motivation and creativity in the classroom and workplace. In Isaksen S G, Murdock M C, Firestien R L, Treffinger D J (eds.) Understanding and recognizing creativity: the emergence of a discipline. Ablex Publishing, Norwood: 400432.

Hodder I (1998) Creative thought: a long-term perspective. In Mithen S (ed.) Creativity in human evolution and prehistory. Routledge, London and New York: 44-56.

Huang T (2009) Creativity theories. In Kerr B (ed.) Encyclopedia of giftedness, creativity, and talent. Sage Publications, London: 216-219.

John G (2004) Counter-Tribes, global protest and carnivals of reclamation. Peace Review, 16(4): 421-428.

Jordan J (2002) The art of necessity: the subversive imagination of anti-road protest and reclaim the streets. In Duncombe S (ed.) Cultural resistance reader. Verso, London: 347-357.

Klein N (2001) Reclaiming the commons. New Left Review, 9: 81-89.

Klein N (2000) No Logo. Harper Perennial, London.

Kozbelt A, Beghetto R, Runco M (2010) Theories of creativity. In Kaufman J, Sternberg R (eds.) The international handbook of creativity.
Cambridge University Press, Cambridge: 20$-47$.

Landry C (2000) The creative city: a toolkit for urban innovators. Earthscan Publications, London.

Landry C, Bianchini F (1995) The creative city. Demos, London.

Leslie D (2005) Editorial: creative cities? Geoforum, 36: 403-405.

Markusen A (2006) Urban development and the politics of a creative class: evidence from a study of artists. Environment and Planning A, 38(10): 1921-1940.

Massey D (2008) Geographies of solidarities. In Clark N, Massey D, Sarre P (eds.) Material geographies: a world in the making. Sage Publications, London: 311-353.

McKay G (ed.) (1998) DiY Culture: Party \& Protest in Nineties Britain. Verso, London.

Meusburger P, Funke J, Wunder E (2009) Introduction: the spatiality of creativity. In Meusburger P, Funke J, Wunder E (eds.) Milieus of creativity: an interdisciplinary approach to spatiality of creativity. KTS and Springer, Heidelberg: 1-10.

Nicholls W J (2007) The geographies of social movements. Geography Compass, 1(3): 607$-622$.

O'Connor J (2004) "A special kind of city knowledge": innovative clusters, tacit knowledge and the "creative city". Media International Australia, 112: 131-149.

Pacione M (2009) Urban geography. $3^{\text {rd }}$ Ed. Routledge, New York.

Panelli R (2004) Social geographies. Sage Publications, London.

Pasquinelli M (2008) Animal spirits: a bestiary of the commons. NAi Publishers, Rotterdam.

Peck J (2005) Struggling with the creative class. International Journal of Urban and Regional Research, 29(4): 740-770.

Plucker J (2005) The (relatively) generalist view of creativity. In Kaufman J, Baer J (eds.) Creativity across domains: faces of the muse. Lawrence Erlbaum Associates, New Jersey: 307-312.

Pratt A (2008) Creative cities: the cultural industries and the creative class. Geografiska Annaler: Series B, Human Geography, 90(2): 107-117.

Purcell M (2008) Recapturing democracy: neoliberalization and the struggle for alternative urban futures. Routdlege, New York and London. 
Raunig G, Ray G, Wuggenig U (2011) Introduction: on the strange case of "creativity" and its troubled resurrection. In Raunig G, Ray G, Wuggenig U (eds.) Critique of creativity: precarity, subjectivity and resistance in the "creative industries". MayFlyBooks, London: $1-5$.

Richards R (2010) Everyday creativity: process and way of life - four key issues. In Kaufman J, Sternberg R (eds.) The international handbook of creativity. cambridge University Press, Cambridge: 189-215.

Richards R (2007) Everyday creativity and the arts. World Futures, 63: 500-525.

Runco M (1996) Personal creativity: definition and developmental issues. New Directions for Child and Adolescent Development, 72: 3-30.

Sawyer R (2006) Explaining creativity: the science of human innovation. Oxford University Press, Oxford.

SchNEWS (2000) Space is the place: direct action and geography. Antipode, 32(2): 111-114.

Scott A J (2006) Creative cities: conceptual issues and policy questions. Journal of Urban Affairs, 28(1): 1-17.

Seixas J, Costa P (2011) Criatividade e governança na cidade: a conjugação de dois conceitos poliédricos e complementares. Cadernos Metrópole, 13(25): 69-92.

Shepard B, Bogad L, Duncombe S (2008) Performing vs. the Insurmountable: theatrics, activism, and social movements. Liminalities: $A$ Journal of Performance Studies, 4(3): 1-30.
Smith N (2002) New globalism, new urbanism: gentrification as global urban strategy. Antipode, 34(3): 434-457.

Soja E (2010) Seeking spatial justice. University of Minnesota Press, Minneapolis.

Stein M I (1953) Creativity and culture. Journal of Psychology, 36: 311-322.

Sternberg R (2006) Introduction. In Kaufman J, Sternberg R (eds.) The international handbook of creativity. Cambridge University Press, Cambridge: 1-9.

Sternberg R J, Lubart T I (1999) The concept of creativity: prospects and paradigms. In Sternberg R J (ed.) Handbook of creativity. Cambridge University Press, New York: 3-15.

Stevens K (1995) Carnival: fighting oppression with celebration. Totem: The University of Western Ontario Journal of Anthropology, 2(1): 65$-68$.

Stokes P (2006) Creativity from constraints: the psychology of breakthrough. Springer Publishing Company, New York.

Swyngedouw E, Kaika M (2003) The making of "glocal" urban modernities. City, 7(1): 5-21.

Taylor V, Dyke N (2004) “Get up, Stand up": tactical repertoires of social movements. In Snow D, Soule S, Kriesi H (eds.) The blackwell companion to social movements. Blackwell Publishing, Oxford: 262-293.

Vargas H, Lisboa V (2011) Dinâmicas espaciais dos grandes eventos no cotidiano da cidade: significados e impactos urbanos. Cadernos Metrópole, 13(25): 145-161.

i This article deals exclusively with the original London-based Reclaim the Streets. 